\section{Short term effect of treating claw horn lesions in dairy cattle on their locomotion, activity and milk yield}

\author{
Jane A. Montgomery, ${ }^{1}$ Katie Forgan, ${ }^{2}$ \\ Catherine Hayhurst,2 Elizabeth Rees,² \\ Jennifer S. Duncan, 2 Jacques Gossellein,3 \\ Charles Harding, ${ }^{4}$ Richard D. Murray ${ }^{2}$ \\ 1Daleside Veterinary Group, Elm Wood, \\ Pandy Industrial Estate, Pandy, \\ Wrexham, Clwyd; 2University of \\ Liverpool School of Veterinary Science, \\ Leahurst Campus, Neston, Wirral; \\ 3Pfizer Ltd, Ramsgate Road, Sandwich, \\ Kent; ${ }^{4}$ Upper Lacon Farm, Prees, \\ Whitchurch, Shropshire, UK
}

Abstract

The immediate effect on dairy cow mobility, daily activity and milk yield following treatment for claw horn disease was examined in 306 lame cows located on four Cheshire dairy farms over twelve months. The daily activity and milk yield of all cows in these herds was recorded on computer using pedometers and in-parlour milk flow meters. Lame cows identified by stockmen were assessed subjectively by locomotion score, then restrained and their claws examined to identify the predominant lesion present. Those with locomotion scores $\geq 2.5$ that presented with sole ulcer, haemorrhage and bruising, or white line disease were studied. Claws of the affected limb were trimmed by one paraprofessional claw trimmer using the five-step Dutch method and the affected claw unloaded either by trimming or application of a block to the healthy digit: those on the contra-lateral limb were trimmed similarly. The same observer repeated the locomotion score assessment seven days later: trimming reduced the proportion of lame cows (score $\geq 3$ ) by $55 \%$ and those with poor gait (score $\leq 3 \geq 2.5$ ) by $49 \%$, and the proportion of all cows not lame after trimming was $51 \%\left(\chi^{2} 4.94\right.$ : $\left.P \leq 0.001\right)$. Night time activity levels increased from 76 to 81 steps/hour on day 2 after treatment $(\mathrm{P}<0.05)$ but this was not maintained: daily milk yields fell by $2 \%$. Using univariate mixed models, year and season, parity and farm all had significant effects on locomotion and activity levels. This treatment for claw horn disease in lame dairy cows improved their immediate health and welfare.

\section{Introduction}

In the United Kingdom, lameness in dairy cattle is one of the most important diseases creating poor welfare for affected cows and substantial economic loss at a herd level. Kossaibati ${ }^{1}$ estimated that, for a case of sole ulcer, the direct costs of treatment were $£ 152$ and the indirect costs three times that amount through culling chronically affected cows, lowered fertility and milk production. Similar observations have been made in other countries with an intensive dairy livestock industry. $2-5$

Pain experienced by a lame cow can be assessed practically using indirect, cow-related parameters, the various methods each having their own inherent strengths and weaknesses. Subjectively, locomotion ${ }^{6}$ or mobility scores indicate degrees of abnormal posture or gait and do not require the cow to be restrained or confined, whilst an exaggerated sensitivity to pain must be measured by applying a point force to the sole horn of the affected foot itself. ${ }^{7}$ Objectively, daily activity is influenced adversely by pain associated with claw horn disease ${ }^{8}$ and this can be measured using pedometers. Measuring changes in response to pain, whether related to extension of soft tissue pathology within the claw horn capsule as an untreated lesion develops or the result of effective treatment of claw horn disease is a different matter. Subjective scoring systems are crude and insensitive, and the hyperalgesia associated with chronic claw horn disease develops slowly and persists for several weeks after treatment has been administered. ${ }^{7}$ Daily activity is a little more sensitive; its decrease following an insult to the foot or increase following successful treatment can be detected within a few days. ${ }^{9}$

A consistent, effective treatment for claw horn disease in dairy cows has been advocated for many years and it is accepted generally that the method described first by Toussaint Raven, ${ }^{10}$ the Dutch method, fulfils this need. Whilst the biomechanical ${ }^{11}$ and anatomical ${ }^{12}$ aspects of this method have been described, the effect of this treatment specifically on the welfare of lame cows has not been reported widely. Blowey ${ }^{13}$ was aware of the importance of unloading diseased claws during treatment, a principle that is now accepted widely by both veterinary clinicians and para-professional claw trimmers alike. ${ }^{14}$

This present study investigated the efficacy of the Dutch method of claw trimming for treating lame cows and its subsequent effect on activity and milk yield in four Cheshire dairy herds.
Correspondence: Dr. Richard D. Murray, University of Liverpool School of Veterinary Science, Leahurst Campus, Neston, Wirral, CH64 7TE, UK.

Tel. +44.151.7946056 - Fax: +44.151.7946065.

E-mail: richmu@liverpool.ac.uk

Key words: bovine, lameness, claw trimming, activity, locomotion score.

Acknowledgements: the authors thank Pfizer Animal Health for supporting this study, and the Cheshire farmers who allowed the research team regular access to their dairy cows throughout the study period

Received for publication: 27 September 2011. Revision received: 4 November 2011.

Accepted for publication: 22 November 2011.

This work is licensed under a Creative Commons Attribution NonCommercial 3.0 License (CC BYNC 3.0).

(C) Copyright J.A. Montgomery et al., 2012

Licensee PAGEPress srl, Italy

Veterinary Science Development 2012; 2:e7 doi:10.4081/vsd.2012.e7

\section{Materials and Methods}

\section{Farms and management}

This study was carried out on four Cheshire dairy farms from November 2006 - October 2007 that housed their milking cows in concrete cubicles covered by mats between the end of October to April and walked on hardcore internal farm tracks to pasture during the grazing period. Cows calved-down throughout the year, avoiding May - July if possible for silage making. Milking cows were all fitted with pedometers just above the fetlock of one hind limb to record daily activity levels as an adjunct to improving heat detection, and daily milk yields were recorded in the milking parlour from in-line flow meters (Crystal: Fullwood Ltd, Ellesmere, Shropshire). Throughout their entire current lactation, these individual cow records were relayed to the farm's computer after each milking where they were stored to produce a daily herd report: also, data was backed up on disc every 24-48 hours. Together with calving date and other fertility management data, a comprehensive record was obtained for every milking cow throughout its current lactation.

\section{Selection and treatment of lame cattle}

The stockmen on each farm identified all cows that were lame and required treatment: there was added incentive for them to do so 
because all treatments were administered without charge. Cows presenting with acute lameness associated with digital infections or trauma were treated immediately by stockmen or veterinary surgeon outside this study. Each week, cows presenting with abnormal gait caused by claw horn disruption were separated from the rest of the herd and examined by the principle investigator (JAM). First, their herd number was recorded, the affected $\operatorname{limb}(\mathrm{s})$ was/were identified and the cow assigned a locomotion score: ${ }^{6}$ then, she was restrained in a crush suitable for trimming feet (Wopa: Lichtenvoorde, the Netherlands) and the affected limb lifted and restrained. The foot was cleaned with fine dry sawdust and all claw horn abnormalities were recorded on a data capture sheet and by digital photography. Cows presenting a new case of lameness defined previously by Clarkson 15 and associated with sole ulcer, haemorrhage and bruising, white line disease including associated abscess, and sole penetration as primary causes of lameness were recruited for investigation: all such cows were treated similarly throughout the entire study period.

For each lame cow, the claws of the affected limb were trimmed by one para-professional claw trimmer (C. Harding) according to the five-step Dutch method described by Toussaint Raven. ${ }^{10}$ Farrier's clippers were used to remove horn from the toe: a power tool with small cutting blades located on a disc was used to remove horn only from the abaxial wall of claws; sole and heel horn was removed and axial wall modelling was carried out always using a knife. If it was not possible to unload the claw presenting the primary lesion associated with that episode of lameness, a wooden block was applied to the sound claw of that foot that was removed six weeks later. Both claws of the contra-lateral limb were always trimmed.

\section{Data collection, handling and analysis}

On the day of enrolment into the study, defined as day 0 , an individual cow data capture sheet was completed for each new case of lameness. This recorded the herd identity, cow ear tag and herd numbers, limb(s) affected and locomotion score, site and description of the primary claw horn lesion associated with lameness and any secondary lesions found on other claws trimmed, and date of trimming. Seven days later, day +7 , the locomotion score was again estimated (by JAM) and recorded.

Individual cow data were obtained from the computerised daily herd reports recorded and stored using on-farm computers, including current calving date and parity. Cow activity levels between milkings were abstracted for the 24 hour periods five days (days -5 to -1 ) before enrolment and the ten days (days +1 to +10) immediately following trimming: similarly, the daily milk yield (kg) throughout the same period. For activity, each numerical value obtained was divided by the number of hours preceding that milking, to investigate activity per hour before and after trimming. For milk yield, only the daily yield was considered. Together with the clinical data, these were combined to form one dataset for each herd, using an Excel spreadsheet, to produce a complete, continuous individual cow record related to their lameness and treatment. These farm data were cleaned: later, the four files were merged to investigate the mixed effects on treatment outcome. ASREML (version 2: VSN International Ltd, Hemel Hempstead, UK) and SPSS (version 16:SPSS Inc., Chicago, IL, USA) software was used for data analysis. Differences before and after trimming for each lame cow, their locomotion score, activity and daily milk yield, were investigated using the Wilcoxan Signed Rank Test. The effect of trimming lame cows within each herd was assessed using chi-square analysis.

Data describing locomotion score, daily activity and milk yield were examined for normality and found to be non-normal. These were $\log _{\mathrm{e}}$ transformed to give normally distributed residuals and allow additional univariate mixed model analysis.

Activity data and milk yield for the days of treatment (day 0) and reassessment of locomotion (day 7) were not used in this analysis because of the disruption caused by herding, handling and foot examination to cows' normal activity on these days.

Univariate mixed models were fitted to locomotion score, mean activity for the day and night time periods and daily milk yield for days -5 to $-1,+1$ to +5 , and +7 to +10 , and the inclusion in the models of various independent fixed variables, random and nested effects was investigated. The final model fitted for each of these outcomes (Y) included the fixed effects of farm $(\mathrm{Fm})$, day relative to treatment ( $\mathrm{D} i)$, season $(\mathrm{Sr})$, year of trimming $(\mathrm{Y} j)$, and cow parity $(\mathrm{P} k)$, and nested farm effects (FSmr): random effects considered were block (B), animal (A) and random error term ( $\varepsilon$ ). Additionally, the locomotion model included the limb - front $(\mathrm{N} p)$ or hind $(\mathrm{H} n)$ - presenting the primary lesion and the milk yield model included the covariate effect of stage of lactation $(\mathrm{L} n)$. The models were:

locomotion: Yijkmntq $=\alpha+\mathrm{D} i+\mathrm{Y} j+\mathrm{P} k+\mathrm{F} m+\mathrm{H} n$ $+\mathrm{N} t+\mathrm{A} i j k m n t q+\varepsilon i j k m n t q$ activity: $\quad$ Yijkmrpq $=\alpha+\mathrm{D} i+\mathrm{Yj}+\mathrm{P} k+\mathrm{F} m+\mathrm{S} r+$ $\mathrm{FS} m r+\mathrm{B} i j k m r p q+\mathrm{A} i j k m r p q+\varepsilon i j k m r p q$ milk yield: $\mathrm{Y} i j m s p q=\alpha+\mathrm{D} i+\mathrm{Y} j+\mathrm{F} m+\mathrm{L} s+\mathrm{B} i j m s p q$ + Aijmspq+eijmspq

Differences between farms, and independent variables affecting treatment outcome, with values of $\mathrm{P}<0.05$ were considered significant.

\section{Results}

During the study period, 306 new cases of lameness associated with claw horn disruption were treated by claw trimming. Data describing the herd sizes, number of cows in-milk, distribution of cases between farms, and the specific lesions considered to be primary causes of lameness are summarised in Table 1. Within all four herds, $94 \%$ of primary lesions were found in the lateral hind claw with very little variation between herds. The predominant lesion associated with horn disruption was sole ulcer, accounting for $72 \%$ of all primary lesions recorded except on Farm $\mathrm{C}$ where the proportion was 53\%: white line disease accounted for $24 \%$ of lame cows on Farms C and D. Sole haemorrhage and bruising due to claw overload was a primary cause of lameness in only $9 \%$ of cases investigated, but was present as a secondary lesion in the contra-lateral limb digits of $62 \%$ of cows presenting other claw horn lesions.

The age profile of lame cows is shown in Figure 1: overall, $16 \%$ of cows trimmed were first lactation heifers but this proportion var-

Table 1. Herd size and numbers of cows in-milk, cows treated following lameness, and primary claw horn lesions recorded on four Cheshire dairy herds, December 2006 - November 2007.

\begin{tabular}{|c|c|c|c|c|c|c|c|}
\hline \multirow[t]{2}{*}{ Farm } & \multicolumn{3}{|c|}{ Numbers of cows } & \multicolumn{4}{|c|}{ Primary lesion associated with lameness } \\
\hline & Herd & In-milk & Treated & Sole ulcer & $\begin{array}{l}\text { Sole haemorrhage } \\
\text { and bruising }\end{array}$ & $\begin{array}{l}\text { White line } \\
\text { disease }\end{array}$ & $\begin{array}{c}\text { Sole } \\
\text { penetration }\end{array}$ \\
\hline A & 340 & 318 & 122 & 87 & 22 & 7 & 6 \\
\hline B & 180 & 176 & 51 & 41 & 1 & 7 & 2 \\
\hline $\mathrm{C}$ & 380 & 322 & 83 & 44 & 2 & 20 & 17 \\
\hline D & 240 & 206 & 50 & 32 & 2 & 12 & 4 \\
\hline
\end{tabular}


ied between farms. The average number of days into lactation when lame cows were treated was $167 \pm 6$ days, and there was no significant difference between farms.

\section{Locomotion score}

Differences in the numbers of cows assigned scores before trimming (day 0 ) and seven days later (day 7) are shown in Figure 2, and were significant $(P \leq 0.001)$. Trimming reduced the proportion of lame cows (score $>3$ ) by $55 \%$ and of those with poor gait but not favouring a particular limb (score 2.5) by $49 \%$ : the proportion of all cows not lame after trimming was $51 \%$ (chi-square $4.94, P \leq 0.001$ ).

The effect of parity and season of treatment is summarised in Table 2 . The mean scores are numbers only and do not equate with degrees of mobility or lameness within cow groupings. The mean score value of all treated heifers and cows was reduced significantly $(\mathrm{P}<0.05)$ : the most significant improvement was found in first lactation heifers compared to older cows. Those milking cattle treated in the summer months when out at grass responded better to trimming than those trimmed whilst partially or completely housed $(\mathrm{P}<0.001)$.

The effect on locomotion of the independent variables investigated by the mixed models is summarised in Table 3. Parity had the greatest effect with lower scores found both before and after trimming in first lactation heifers compared to older cows. The farm effect was significant; on Farm B, lame cows had lower scores than the other three farms. Cows presenting with sole haemorrhage and bruising had lower scores than those lame because of sole ulcer, white line disease or sole abscesses.

\section{Activity per hour}

Overall, the mean activity level between days -5 to -1 was 133 steps per hour during the day and 88 per hour at night before trimming; after treatment day time activity remained the same but night activity rose initially to 92 steps per hour. However, this increase in activity levels was not maintained and for the period $+7-10$ days after trimming it had returned to the original baseline level (Figure 3). Pair wise analysis showed that night time activity increased significantly compared to the baseline only on day $+2(\mathrm{P} \leq 0.05)$.

Differences in mean values for activity per hour before and after treatment, dependent on parity, season of trimming and lesion type, are shown in Table 4. Lesions were placed in two categories: claw horn disruption caused by sole ulcer, white line disease and sole abscess, and overload related to sole haemorrhage and bruising. Variables increasing activity after treatment for either category were inconsistent: when trimming was carried out in the winter housing period, night time activity had reduced significantly by eight days after treatment.

Table 5 summarises the fixed effects associated with day and night time activity for all lame cows. The year of treatment was most influential, reflecting the time when lame cows were recruited into the trial by stockmen. Besides this factor, the most consistent significant effect was associated with the season when treatment was carried out. Activity levels were highest during spring and summer and lowest in the winter housing period: night time activity varied less markedly than during the day, irrespective of the season. Treatment improved activity most at turn-out to pasture full time, around March - May: when cows were brought in during the autumn, night time activity fell and this was associated with cows being out during the day time and housed at night. Parity was a significant variable, activity levels being significantly greater in first lactation heifers and lowest in cows that had milked four lactations or more.

\section{Milk yield}

For the five days prior to treatment, mean milk yield was 26.1 (se 0.62) litres: this fell on the day after trimming by 1.3 litres $(\mathrm{P}<0.01)$. Since most lame cows were treated $140-210$

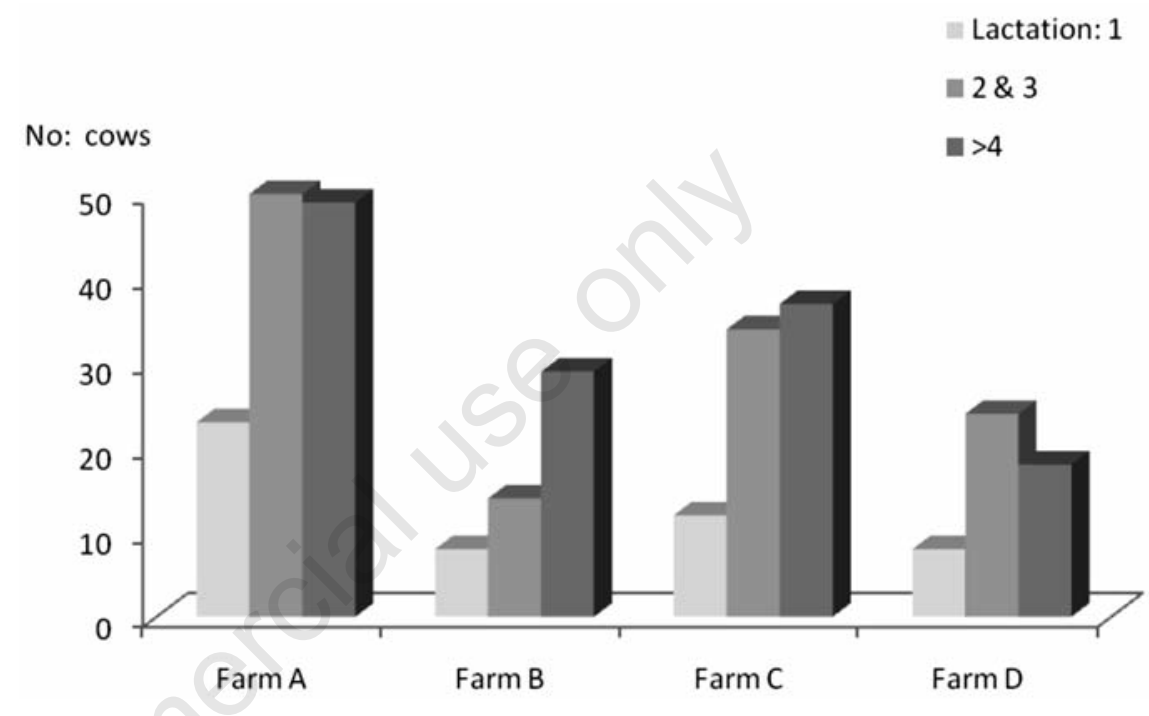

Figure 1. Age profile of 306 lame cows on four Cheshire dairy farms whose claws were trimmed: December 2006 - November 2007.

Table 2. Effect of parity and season of treatment on mean locomotion scores (s.e) recorded in 306 cows on four Cheshire dairy herds, December 2006 - November 2007.

\begin{tabular}{lccc} 
Variable & \multicolumn{2}{c}{ Mean locomotion scores relative to trimming } \\
Day 0 & Day 7 & $\begin{array}{c}\text { Significance } \\
\text { Parity }\end{array}$ \\
1 & $2.75(0.04)$ & $1.98(0.05)$ & $\mathrm{P}<0.05$ \\
$2-3$ & $2.78(0.04)$ & $2.31(0.05)$ & n.s. \\
$\geq 4$ & $2.79(0.03)$ & $2.40(0.06)$ & n.s. \\
Season of treatment & & & \\
Dec-Feb & & & \\
March-May & $2.78(0.05)$ & $2.38(0.07)$ & n.s. \\
June-August & $2.74(0.06)$ & $2.26(0.09)$ & n.s. \\
Sept-Nov & $2.86(0.05)$ & $2.26(0.07)$ & n.s. \\
\hline
\end{tabular}

n.s., not significant.

Table 3. Independent variables affecting locomotion score for 306 dairy cows on four Cheshire dairy herds, December 2006-November 2007.

\begin{tabular}{|c|c|c|c|}
\hline Variable & df & F value & significance \\
\hline Day of treatment & 1 & 261.3 & $\mathrm{P}<0.001$ \\
\hline Parity & 2 & 8.3 & $\mathrm{P}<0.001$ \\
\hline Farm & 3 & 3.2 & $\mathrm{P}<0.05$ \\
\hline Primary presenting lesion: fore limb & 2 & 3.9 & $\mathrm{P}<0.05$ \\
\hline hind limb & 2 & 11.1 & $\mathrm{P}<0.001$ \\
\hline
\end{tabular}


days into lactation their daily milk yields were declining anyhow and it is not possible to state whether this was a direct treatment effect.

The univariate mixed model analysis showed there were significant but equal effects related to trimming: year, season, number of days post-partum, and parity. The farm effect was significant; mean daily milk yield for treated cows on day +1 after treatment on Farms B and C were similar around $23 \mathrm{~L}$ but those cows on Farm A averaged only $14 \mathrm{~L} \mathrm{com-}$ pared to 28 litres given by similar cows on Farm D $(\mathrm{P} \leq 0.001)$.

\section{Discussion}

It is accepted generally that the five-step Dutch method for cattle claw trimming is the definitive intervention for treating lame cows both in the UK, 14 northern Europe ${ }^{12,16}$ and north America. 17 There is very little published data describing the locomotion and activity of dairy cows before and immediately after trimming exclusively using this method: this present investigation, conducted for the first time on UK commercial dairy farms, provides just such evidence. Using the subjective measure of locomotion score, claw trimming halved the initial number of cows observed lame or that walked with poor gait: additionally, the objective measure of activity per hour showed an increase of $9 \%$ during the five days immediately following treatment, mostly during the night time period. An earlier study has shown that lame cows were least active at night ${ }^{9}$ and results of this present study indicate that correct claw trimming technique for treating digital horn lesions is most beneficial and pronounced on activity levels during the nighttime period. Furthermore, these results validate this form of treatment for claw horn lesions, since 0 'Callaghan-Lowe ${ }^{14}$ showed that only $36 \%$ of veterinary surgeons and $22 \%$ of paraprofessional claw trimmers in the UK ever check the response of lame cattle following trimming, and much of that evidence is hearsay. Laven ${ }^{4}$ showed a similar improvement in locomotion score immediately after trimming 149 lame dairy cows, all presenting claw horn lesions and farmed under New Zealand conditions, which persisted for up to three months.

Claw trimming alters the initial zone of contact between the sole and the ground. Meyer ${ }^{18}$ studied the locomotion of 18 Brown Swiss heifers: in the lateral hind claw, either the heel or the abaxial wall made contact with the ground first in almost equal numbers of feet; after trimming the initial heel contact increased to $78 \%$ of them. It appears that the lateral hind claw is placed positively on the ground first and that the medial claw place-

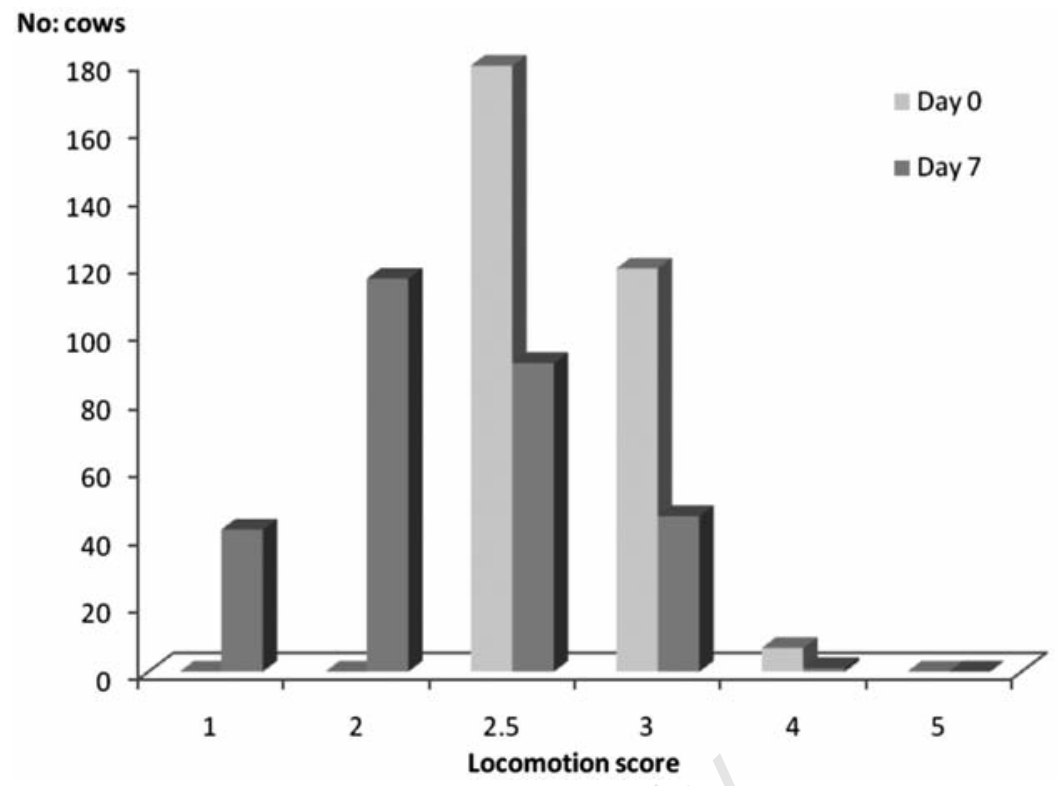

Figure 2. Median locomotion scores of 306 cows before (day 0 ) and after trimming (day 7) on four Cheshire dairy farms: December 2006 - November 2007.

Table 4. Differences in mean activity per hour (s.e) before trimming and days 2 and 8 after treatment for 306 cows according to parity, season of trimming, and lesion type on four Cheshire dairy herds, December 2006 - November 2007.

\begin{tabular}{|c|c|c|c|c|}
\hline Independent variable & & Days -5 to -1 & $\begin{array}{c}\text { activity p } \\
\text { Day +2 }\end{array}$ & Day +8 \\
\hline $\begin{array}{l}\text { Parity: } \\
1\end{array}$ & night & $\begin{array}{c}145(10.5) \\
99(7.2)\end{array}$ & $\begin{array}{l}141(8.9) \\
103(7.0)\end{array}$ & $\begin{array}{c}146(10.0) \\
95(6.6)\end{array}$ \\
\hline $2-3$ & $\begin{array}{l}\text { day } \\
\text { night }\end{array}$ & $\begin{array}{l}134(6.4) \\
92(4.9)\end{array}$ & $\begin{array}{l}139(6.5) \\
97(5.2)\end{array}$ & $\begin{array}{l}144(7.3) \\
90(5.0)\end{array}$ \\
\hline$\geq 4$ & $\begin{array}{l}\text { day } \\
\text { night }\end{array}$ & $\begin{array}{l}127(6.0) \\
79(3.9)\end{array}$ & $\begin{array}{l}128(8.6) \\
87(5.3)^{*}\end{array}$ & $\begin{array}{l}129(7.0) \\
81(5.3)\end{array}$ \\
\hline $\begin{array}{l}\text { Season of treatment: } \\
\text { Dec-Feb }\end{array}$ & $\begin{array}{l}\text { day } \\
\text { night }\end{array}$ & $\begin{array}{l}87(4.8) \\
70(4.3)\end{array}$ & $\begin{array}{l}87(4.6) \\
80(5.7)\end{array}$ & $\begin{array}{l}83(4.0) \\
66(3.5)^{*}\end{array}$ \\
\hline March-May & $\begin{array}{l}\text { day } \\
\text { night }\end{array}$ & $\begin{array}{l}171(11.5) \\
103(8.9)\end{array}$ & $\begin{array}{l}169(12.0) \\
108(9.8)\end{array}$ & $\begin{array}{l}170(11.0) \\
116(11.4)\end{array}$ \\
\hline June-August & $\begin{array}{l}\text { day } \\
\text { night }\end{array}$ & $\begin{array}{l}158(7.4) \\
110(7.3)\end{array}$ & $\begin{array}{l}165(9.4) \\
122(8.2)\end{array}$ & $\begin{array}{c}183(11.4)^{*} \\
106(7.9)\end{array}$ \\
\hline Sept-Nov & $\begin{array}{l}\text { day } \\
\text { night }\end{array}$ & $\begin{array}{l}132(6.8) \\
78(3.3)\end{array}$ & $\begin{array}{c}133(8.9) \\
78(3.5)\end{array}$ & $\begin{array}{l}135(6.2) \\
77(4.0)\end{array}$ \\
\hline Hind limb primary lesion: & & & & \\
\hline Claw horn disruption & $\begin{array}{l}\text { day } \\
\text { night }\end{array}$ & $\begin{array}{l}135(4.6) \\
86(3.1)\end{array}$ & $\begin{array}{c}135(5.3) \\
93(3.7)\end{array}$ & $\begin{array}{l}139(5.1) \\
85(3.5)\end{array}$ \\
\hline Lateral claw overload & $\begin{array}{l}\text { day } \\
\text { night }\end{array}$ & $\begin{array}{l}115(15.6) \\
102(14.6)\end{array}$ & $\begin{array}{l}121(16.1) \\
100(11.8)\end{array}$ & $\begin{array}{c}123(18.0) \\
91(8.9)\end{array}$ \\
\hline
\end{tabular}

Wilcoxan Signed Ranks test: * $\mathrm{P} \leq 0.05$

Table 5. Independent variables affecting activity in $\mathbf{3 0 6}$ dairy cows on four Cheshire dairy herds, December 2006 - November 2007.

\begin{tabular}{|c|c|c|c|c|c|c|}
\hline \multirow{2}{*}{$\begin{array}{l}\text { Period of } \\
\text { activity and } \\
\text { degrees } \\
\text { of freedom }\end{array}$} & \multicolumn{6}{|c|}{ F value for independent variable and its significance } \\
\hline & $\begin{array}{l}\text { Day of } \\
\text { trimming }\end{array}$ & Year & Farm & Parity & $\begin{array}{l}\text { Season of } \\
\text { trimming }\end{array}$ & $\begin{array}{l}\text { Season } \\
\text { within } \\
\text { farm }\end{array}$ \\
\hline df & 9 & 1 & 3 & 2 & 3 & 4 \\
\hline day & 1.38 & $32.42^{* * *}$ & $6.18^{* * *}$ & $6.22^{* *}$ & $18.37^{* * *}$ & $2.96^{*}$ \\
\hline night & $2.06^{*}$ & $10.64^{* *}$ & $7.14^{* * *}$ & $5.25^{* *}$ & $7.93^{* * *}$ & 1.18 \\
\hline
\end{tabular}

Significance: ${ }^{*} \mathrm{P}<0.05 ;{ }^{* *} \mathrm{P}<0.01 ;{ }^{* * *} \mathrm{P}<0.001$. 


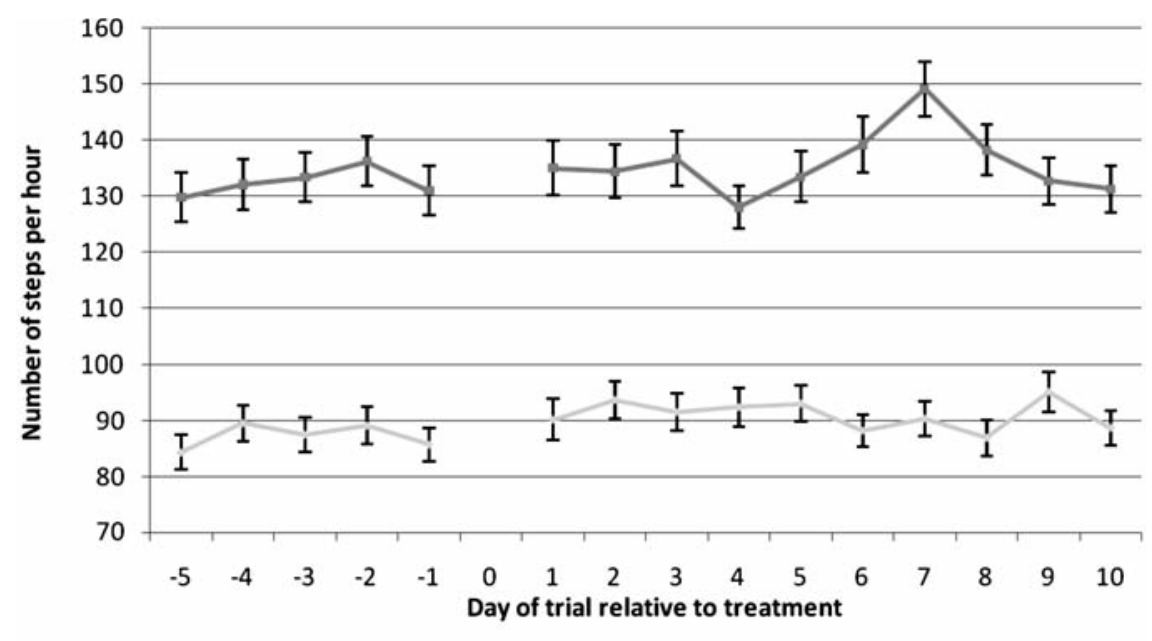

Night $\longrightarrow$ Day

Figure 3. Mean activity values per hour (s.e bars) for day and night time related to the days -5 to -1 days before and +1 to +10 days following treatment.

ment follows almost in an involuntary fashion. Thus, the initial ground reaction force is taken up almost exclusively by the lateral hind claw. Effective claw trimming should shorten the length of the dorsal wall of the lateral claw in particular, and it is this that ensures the initial contact and impact force of the claw with the ground occurs more at the heel. Claw trimming reduces points of maximal pressure away from the sole heel junction, and abaxial white line and adjacent sole, redistributing that pressure somewhat to the stable medial claw. ${ }^{19}$ The resulting improved stable contact area between the heel, abaxial and axial walls of the claw horn capsule and the ground creates more resistance provided by these vertical surfaces: this increases the frictional characteristics of trimmed claws that helps reduce the incidence of slipping by cattle housed on concrete. 20 This present study suggests that the theoretical science that underpins the Dutch method of claw trimming is indeed effective when applied onfarm, particularly to cows which have poor gait characteristics but are not walking lame on a particular limb. Our results show that the locomotion of just under half of those cows with poor gait, the majority of which had sole haemorrhage and bruising as either a primary or secondary lesion, was improved significantly either when housed or at pasture.

This present study has shown that parity is a very significant factor associated with locomotion and activity levels. Both these measures were best in first lactation heifers compared to older cows, irrespective of farm or seasonal effect when lameness occurred that required treatment. There may be several reasons for this. First, the patho-physiological changes that occur around calving and alter the anatomical relationships between third phalanx and claw horn capsule ${ }^{21}$ may not cause permanent anatomical changes in the feet of first lactation heifers, providing their housing and nutrition are of an acceptable standard. If they are, both lesion and locomotion scores improve without treatment 22,23 but if poor husbandry factors remain, lameness and accompanying pain will result. In a relatively young and fit milking heifer that has been treated soon after it has been first observed as lame, hyperalgesia in the affected claw should not become established 24 and locomotion and activity levels may be maintained.

If these same three risk factors reoccur and persist after each subsequent calving, the abnormal anatomical relationships within the claw horn capsule associated with lameness, described by 0 ssent, ${ }^{25}$ may become permanent and locomotion and activity in older lame cows is reduced consequently.

Secondly, continuous exposure to individual but commonplace farm factors that affect adversely gait and activity, such as cubicle size and comfort, ${ }^{26}$ indoor and outdoor walking surfaces, ${ }^{27}$ and quality and frequency of claw trimming 28 increase the probability that older cows will become lame.

Thirdly, the pathological changes that occur in claw horn diseases causing lameness in first lactation heifers are a precursor for later lameness events in the same cow. ${ }^{29}$ The results presented in this paper suggest that good management of first lactation heifers is crucial for maintaining their continuing good welfare throughout the remainder of their productive lives within the dairy herd.

This present study investigated locomotion and activity only in the period immediately after trimming, albeit mostly in cows in midlactation. There are very few reports describing the medium and long term benefit of claw trimming dairy cows at a similar stage of lactation, compared to when cows are dried off: in a study of one herd of 333 dairy cows,
Hernandez ${ }^{30}$ showed a $25 \%$ efficiency of claw trimming for reducing lameness during the remainder of the lactation, the dry period, and for up to six months into the following lactation. They estimated the costs of treating and preventing lameness in cows at this stage of lactation was around $£ 60$, attributable only to lower milk production. However, they considered it more important to reduce the overall subsequent incidence of claw horn disease in these cattle, from an animal welfare perspective. The Dutch method used in this present study would have achieved a similar outcome since the contra-lateral claws were trimmed also, not just those associated with the lame foot.

In conclusion, these authors believe that by using observational and objective data to describe cows' locomotion and activity before and after treating claw horn disease using the Dutch method, and applying robust data analysis, they have responded to the plea by Logue ${ }^{31}$ that everybody who trims cows' feet should take care...when attempting to balance the foot...(our) primary concern must be an overriding duty to the cow and improve her welfare.

\section{References}

1. Kossaibati MA, Esslemont RJ. The costs of production diseases in dairy herds in England. Vet J 1997;154:41-51.

2. Fitzgerald T, Norton BW, Elliott R, Podlich $\mathrm{H}$, Svendsen OL. The influence of longterm supplementation with biotin on the prevention of lameness in pasture fed dairy cattle. J Dairy Sci 2000;83:338-44.

3. Donovan GA, Risco CA, Dechant Temple $\mathrm{GM}$, et al. Influence of transition diets on occurrence of subclinical laminitis in Holstein dairy cows. J Dairy Sci 2003; 87: 73-84.

4. Laven RA, Lawrence KE, Weston JF, et al. Assessment of the duration of pain response associated with lameness in dairy cows, and the influence of treatment. N Z Vet J 2008;56:210-7.

5. O'Driscoll KKM, Hanlon A, French P, Boyle LA. The effects of two out-wintering pad systems compared with free-stalls on dairy cow hoof and limb health. J Dairy Res 2009;76:59-65.

6. Manson FJ, Leaver JD. The influence of concentrate amount on locomotion and clinical lameness in dairy cattle. Anim Prod 1988;47:185-90.

7. Whay HR, Waterman AE, Webster AJF, 0 'Brien JK. The influence of lesion type on the duration of hyperalgesia associated with hindlimb lameness in dairy cattle. Vet J 1998;156:23-9.

8. 0'Callaghan KA, Cripps PJ, Downham DY, 
Murray RD. Subjective and objective assessment of pain and discomfort due to lameness in dairy cattle. Anim Welf 2003;12:605-10.

9. 0'Callaghan KA. The control of pain associated with lameness in dairy cattle. $\mathrm{PhD}$ thesis 2003. University of Liverpool, UK.

10. Toussaint Raven E. Cattle Foot Care and Claw Trimming. 1989, Ipswich, Farming Press.

11. van Der Tol PPJ, van Der Beek SS, Metz JHM, et al. The effect of preventive trimming on weight bearing and force balance on the claws of dairy cattle. J Dairy Sci 2004;87:1732-38.

12. Nuss K, Paulus N. Measurements of claw dimensions in cows before and after functional trimming: a post mortem study. Vet J 2006;172:284-92.

13. Blowey RW. Welfare aspects of foot lameness in cattle. Irish Vet J 1998;51:203-7.

14. 0'Callaghan-Lowe KA, Murray RD, Cripps PJ, Ward WR. Working practices of cattle foot trimmers used for footcare in dairy cattle compared with those of veterinary surgeons for treatment of lameness in large animal practice. J Vet Med A 2004; 51:429-34.

15. Clarkson MJ, Faull WB, Hughes JW, et al. Incidence and prevalence of lameness in dairy cattle. Vet Rec 1996;138:563-7.

16. Amory JR, Kloosterman P, Barker ZE, et al. Risk factors for reduced locomotion in dairy cattle on nineteen farms in The
Netherlands. J Dairy Sci 2006;89:1509-15.

17. Shearer JK, van Amstel SR. Functional and corrective claw trimming. Vet Clin N Am Food Anim Prac 2001;17:53-72.

18. Meyer SW, Weishaupt MA, Nuss KA. Gait pattern of heifers before and after claw trimming: a high-speed cinematographic study on a treadmill. J Dairy Sci 2007;90: 670-6.

19. Singh SS. Aetio-pathology of foot lameness in cattle. PhD thesis 1993. University of Liverpool, UK.

20. Phillips CJC, Chiy PC, Bucktrout MJ, et al. Frictional properties of cattle hooves and their conformation after trimming. Vet Rec 2000;146:607-9.

21. Knott L, Tarlton JF, Craft H, Webster AJF. Effects of housing, parturition and diet change on the biochemistry and biomechanics of the support structures of the hoof of dairy heifers. Vet J 2007;174:27787.

22. Webster AJF. Effects of housing practices on the development of foot lesions in dairy heifers in early lactation. Vet Rec 2002;151:9-12.

23. Leach KA, Offer JE, Svoboda I, Logue DN. Effects of type of forage fed to dairy heifers: Associations between claw characteristics, clinical lameness, environment and behaviour. Veterinary $\mathrm{J} 2005$; 169:427-36.

24. LaMotte RH, Shain CN, Simone DA, Tsai E. Neurogenic hyperalgesia: psychophysical studies of underlying mechanisms. J Neurophysiol 1991;66:190-211.

25. Ossent P, Lischer CJ. Bovine laminits: the lesions and their pathogenesis. In Pract 1998;20:415-27.

26. Singh SS, Ward,WR, Lautenbach K, Murray RD. Behaviour of lame and normal dairy cows in cubicles and in a straw yard. Vet Rec 1993;133:204-8.

27. Faull WB, Hughes JW, Clarkson MJ, et al. Epidemiology of lameness in dairy cattle: the influence of cubicles and indoor and outdoor walking surfaces. Vet Rec 1996; 139:130-6.

28. Faye B, Lescourret F. Environmental factors associated with lameness in dairy cattle. Prev Vet Med 1989;7:267-87.

29. Hirst WM, Murray RD, Ward WR, French NP. A mixed-effects time-to-event analysis of the relationship between first lactation lameness and subsequent lameness in dairy cows in the UK. Prev Vet Med 2002; 54:191-201.

30. Hernandez JA, Garbarino EJ, Shearer JK, et al. Evaluation of the efficacy of prophylactic hoof health examination and trimming during midlactation in reducing the incidence of lameness during late lactation in dairy cows. J Am Vet Med Ass 2007;230:89-93.

31. Logue DN, Offer JE, Murray RD. Improving claw trimming in cattle: onwards from the Dutch technique. Vet J 2006;172:204-5. 